Departement für Nutztiere der Vetsuisse-Fakultät

Universität Zürich

Klinik für Fortpflanzungsmedizin

(Direktor: Prof. Dr. W. Kähn) und

Arbeit unter der Leitung von Dr. F. Janett

\title{
Influence of estradiol on adrenal activity in ovariectomized cows during acute stress
}

\author{
INAUGURAL-DISSERTATION \\ zur Erlangung der Doktorwürde \\ der Vetsuisse-Fakultät \\ Universität Zürich \\ vorgelegt von \\ Kathrin Hollenstein \\ Tierärztin \\ von Bichelsee \\ Genehmigt auf Antrag von \\ Prof. Dr. R. Thun, Referent \\ Prof. Dr. F.R. Althaus, Korreferent
}

Zürich 2005

Stiftung Zentralstelle Studentendruckerei 
FÜR

MEINE ELTERN, DIE ES MIR ERMÖGLICHTEN DEN SCHÖNSTEN BERUF ZU

ERLERNEN

MEINEN MANN, DER VIEL VERSTÄNDNIS FÜR DEN SCHÖNSTEN BERUF AUFBRINGT 


\title{
Einfluss von Oestradiol auf die NNR-Aktivität unter akutem Stress bei ovarektomierten Kühen
}

\author{
K. Hollenstein, F. Janett, U. Bleul, M. Hässig, W. Kähn, R. Thun \\ Klinik für Fortpflanzungsmedizin, Universität Zürich, \\ Winterthurerstrasse 260, 8057 Zürich, Schweiz
}

\section{Zusammenfassung}

Die stressbedingte Aktivierung der hypothalamo-hypophyseo-adrenocorticalen (HHA)Achse kann die Sexualfunktion bei Mensch und Tier beeinträchtigen. Andererseits ist auch bekannt, dass Oestrogene in der Lage sind, die NNR-Aktivität zu beeinflussen. In der vorliegenden Arbeit wurden die Auswirkungen von Oestradiol-17ß (E2) auf die Sekretion von Cortisol, Progesteron und LH bei ovarektomierten Kühen während einer akuten Stressbelastung (Immobilisation im Klauenstand während 2 Stunden) untersucht. Dazu wurden 5 ovarektomierte Kühe, je einmal mit und ohne E2-Substitution, dem akuten Stressor ausgesetzt und anhand frequenter Blutentnahmen (alle 15 Minuten) während 5 Stunden der Verlauf von Cortisol, Progesteron und LH bestimmt. Unsere Ergebnisse zeigen, dass die 2-stündige Stressphase bei Kühen unabhängig von E2 zu einer signifikanten $(P<0.05)$ Erhöhung von Cortisol führte. Die durchschnittlichen Progesteronwerte erhöhten sich ebenfalls während der Stressphase doch war die Zunahme nur bei Kühen ohne E2-Behandlung signifikant. Im Gegensatz zu Cortisol und Progesteron erniedrigten sich die LH-Konzentrationen während der Stresseinwirkung wobei der durchschnittliche LH-Wert am Ende der Belastung signifikant tiefer war als vor der Stresseinwirkung. Bei allen Kühen ohne Stress hatte E2 auf den Verlauf aller drei Hormone keinen Einfluss. Unsere Untersuchungen mit ovarektomierten Kühen lassen den Schluss zu, dass a) akuter Stress die Sekretion von Cortisol und Progesteron erhöht, von 
LH jedoch erniedrigt und b) dass die stressinduzierte Reaktion von Nebennierenrinde und Hypophyse unter Einwirkung von Oestradiol abgeschwächt wird. 


\title{
Influence of estradiol on adrenal activity in ovariectomized cows during
}

\section{acute stress}

\author{
K. Hollenstein, F. Janett, U. Bleul, M. Hässig, W. Kähn, R. Thun \\ Clinic of Reproduction, University of Zürich, \\ Winterthurerstrasse 260, 8057 Zürich, Switzerland
}

\begin{abstract}
Stress dependent activation of the hypothalamo-pituitary-adrenal axis (HPA) can compromise reproductive function in animals and humans. In addition, it has been shown that estrogens are also capable of influencing the activity of the adrenal cortex. The objective of this study was to evaluate the effect of estradiol (E2) on adrenocortical secretion of cortisol and progesterone as well as on pituitary LH-release in cows during stress. Five ovariectomized Brown Swiss cows were exposed to acute restraint stress (2-h immobilization in a trimming chute), either with or without E2 treatment. Blood samples were taken every $15 \mathrm{~min}$ during a 5 -h period for determination of cortisol, progesterone and LH. Our results demonstrate that during the 2-h stress period mean cortisol concentrations significantly $(P<0.05)$ increased in all cows independent of E2 treatment. Mean progesterone concentrations also increased during stress, but the effect was only significant in E2-untreated cows. In contrast to cortisol and progesterone mean LH values decreased in all animals during stress, but the decline was not significant. However, significantly lower mean LH values were seen at the end of the stress period comparing to values before stress. In cows without stress, E2 treatment had no significant effect on mean values of all three hormones analyzed. From our results it can be concluded that in ovariectomized cows a) acute stress increases cortisol and progesterone secretion but decreases LH release and b) the stress induced adrenocortical and pituitary responses were clearly attenuated under the influence of estradiol.
\end{abstract}




\section{Introduction}

The influence of stress on reproductive function in man (Chrousos et al., 1998) and animals (Rivier and Rivest, 1991; Tilbrook et al., 2000; Dobson et al., 2003) has been subject of many studies. As early as 1932, Selye observed that in rats, stress led to increased activity of the hypothalamo-pituitary-adrenal (HPA) axis and to decreased reproductive performance. He concluded that there might be a link between the hormones of the HPA axis and those of the hypothalamo-pituitary-gonadal (HPG) axis. Effects of stress on reproductive activity has been described in many species, amongst others in rats (Higuchi et al., 1986; Carey et al., 1995; Kam et al., 2002; Li et al., 2004), sheep (Dobson and Smith, 1995; Tilbrook et al., 1999a; Daley et al., 2000; Smith and Dobson, 2002; Turner et al., 2002; Dobson et al., 2003), cows (Da Rosa and Wagner, 1981; Dobson and Smith, 1995; Kaufmann, 1997; Thun et al., 1998), rhesus monkeys (Chen et al., 1992) and humans (Saketos et al., 1993; Chrousos et al., 1998; Ferin, 1999). These studies show that the stress hormones corticotropin-releasing hormone (CRH), $\beta$-endorphin (END), vasopressin (AVP), adrenocorticotropin (ACTH) and cortisol (C) can influence several hormones of the HPG axis, such as gonadotropin-releasing hormone (GnRH), LH and FSH as well as estradiol (E2) and progesterone (P), both centrally and peripherally. A dominant role is played by $\mathrm{CRH}$, which stimulates the secretion of ACTH from the pituitary gland and influences GnRH secretion from the hypothalamus. However, species specific reactions have been recorded in several studies showing that intravenous application of CRH inhibits LH secretion in monkeys (Gindoff and Ferin, 1987; Xiao et al., 1989; Chen, 1996) and humans (Barbarino et al., 1989), whereas in rats intracerebro-ventricular application is needed for the same effect (Rivier and Rivest, 1991; Rivest and Rivier, 1995; Li et al., 2004). Conversely, intracerebro-ventricular application of CRH in sheep caused a rise in LH secretion (Naylor et al., 1990; Caraty et al., 1997; Tilbrook et al., 1999b). In cows, it has been shown that under the influence of ACTH the adrenal cortex secretes not 
only cortisol but also sexual steroids which through feedback mechanisms can have an effect on reproductive function (Da Rosa and Wagner, 1981). Furthermore, several studies (Stoebel and Moberg, 1982; Dobson, 1987; Nanda et al., 1990) have concluded that in cows the preovulatory LH peak can be significantly decreased or totally suppressed by acute stress. Caraty et al. (1997) found that this effect was subject to the presence of sexual steroid hormones. Investigations on intact, cyclic cows (Kaufmann, 1997; Thun et al., 1998) have proved that acute immobilization stress can lead to increased secretion of cortisol, progesterone and LH during estrus but not in diestrus. However, in these studies no attempt has been made to measure the effect of estradiol on either the adrenal or gonadal system. Studies in ovariectomized rats (Hahn et al., 2003), sheep (Ozturk et al., 1998; Tilbrook et al., 1999a) and cows (Wolfe et al., 1992) have shown that 17ß-estradiol can have an inhibitory effect on the pulsatile release of LH especially when given in higher doses.

The aim of the present study was to examine the effect of $17 \beta$-estradiol on the secretion of cortisol, progesterone and LH in ovariectomized cows subjected to acute immobilization stress.

\section{Materials and methods}

\subsection{Animals}

Five lactating, ovariectomized Brown Swiss cows, between 3 and 9 years old, were used for the experiments. Ovariectomy took place 3 months before the start of the experiment and was carried out laparoscopically. Four weeks before the study began, the cows were acclimatized to indoor stalls. They had daily access to pasture and were fed twice daily with hay and $1 \mathrm{~kg}$ commercial pelleted diet. Water was provided ad libitum. All animal experimentation was performed following approval from the Animal Ethics Committee (approval Nr. 76/2002). 


\subsection{Experimental design}

To test the influence of $17 \beta$-estradiol (E2) on hormone secretion under stress, the cows were exposed to 2-h immobilization stress in a trimming chute, with the left and the right hind leg being fixed for $1 \mathrm{~h}$ each. After the exposure to stress, the cows were returned to their stalls and blood sampling continued for a further $3 \mathrm{~h}$. As each animal served as its own control, hormone profiles were also established in all cows without stress during the experiment. Therefore the whole study consisted of 4 treatment regimens arranged in the following order: treatment 1 , without stress and without E2; treatment 2, with stress and without E2; treatment 3, without stress and with E2; treatment 4, with stress and with E2. The whole experiment lasted 3 weeks and was performed during the month of August. Between the treatments without E2 (treatments 1 and 2) and with E2 (treatments 3 and 4) a one week interval was used for estrogen priming. To rule out the effect of circadian fluctuations, the single treatments were always carried out from 9 am to $2 \mathrm{pm}$.

\subsection{Estradiol treatment}

All cows received $2 \mathrm{mg}$ oil based estradiol-benzoate (Veterinaria AG, Zürich, Switzerland) i.m. 6 days before the start of treatments 3 and 4 . Five and 4 days before beginning each cow received further doses of $10 \mathrm{mg}$ crystalline $17 \beta$-estradiol (Oestradiol K ${ }^{\circledR}$, Streuli, Uznach, Switzerland) and 1 day before the start of treatment an additional dose of $1 \mathrm{mg}$ estradiol-benzoate was given i.m. This treatment schedule led to plasma estradiol concentrations between 20 and $50 \mathrm{pg} / \mathrm{ml}$ in all animals.

\subsection{Blood collection}

Blood was collected via an indwelling catheter (Peal-Away-Cook ${ }^{\circledR}$, Cook AG, Sursee, Switzerland) placed in the jugular vein. The catheter was inserted the day before each treatment. After every blood sample the catheter was flushed with heparinized physiological saline solution (25 IU heparin/ml). For documentation of short-term hormone fluctuations blood was collected every 15 min during the 5-h treatment period in 
EDTA coated Vacutainers ${ }^{\circledR}$ (Aichele-Medico, Basel, Switzerland), immediately centrifuged $\left(1000 \times \mathrm{g}, 10 \mathrm{~min}, 4^{\circ} \mathrm{C}\right)$ and stored at $-20^{\circ} \mathrm{C}$ until hormone analysis.

\subsection{Hormone analysis}

Cortisol (C), progesterone (P) and 17ß-estradiol (E2) were determined by enzyme immunoassay, previously described by Sauerwein (1991) and Meyer (1990). The sensitivity for progesterone was $0.1 \mathrm{ng} / \mathrm{ml}$, for cortisol $0.5 \mathrm{ng} / \mathrm{ml}$ and for $17 \beta$-estradiol 0.12 pg/ml. LH was determined by radioimmunoassay (Schams and Karg, 1969) with a sensitivity of $0.25 \mathrm{ng} / \mathrm{ml}$.

\subsection{Statistitical analysis}

Data were analyzed using StatView 5.0 software program (SAS Institute, Dübendorf, Switzerland). A multivariate analysis of variance (ANOVA) with repeated measures was carried out and the effects of different test series were compared with Fisher's post hoc test. Mean LH values immediately before and after stress were compared by paired $t$-test. Data are presented as mean \pm standard error of mean ( $m \pm$ S.E.M.). Values were considered to be statistically significant at $P<0.05$.

\section{Results}

\subsection{Plasma concentrations of cortisol}

The mean $(m \pm$ S.E.M.) cortisol concentrations in cows with and without stress either treated or not treated with E2 are shown in Fig. 1a. During the 2-h period of restraint stress the average cortisol concentrations gradually increased and were significantly $(P<0.05)$ higher than mean values of cows without stress (Table 1). There was a non significant tendency for the E2 treatment to inhibit the stress induced cortisol increase. Under stress the mean plasma cortisol values ranged between $11.5-44.3 \mathrm{ng} / \mathrm{ml}$ in cows without E2 and 9.6-29.8 $\mathrm{ng} / \mathrm{ml}$ in cows with E2. Without stress the mean plasma cortisol concentrations fluctuated between 2.9-9.1 ng/ml, independent of E2 treatment. 

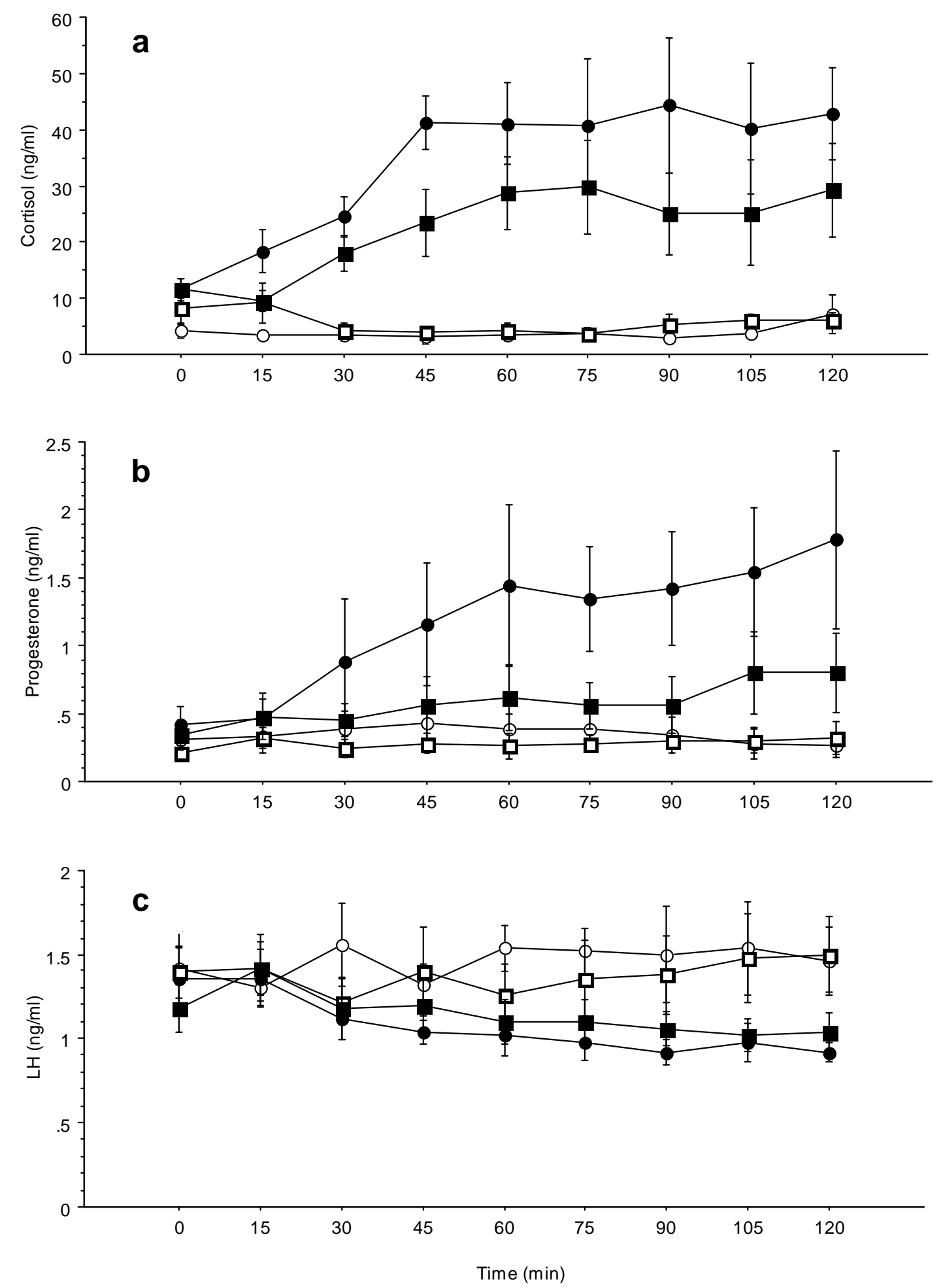

Fig. 1. Mean ( $m \pm$ S.E.M.) plasma concentrations of cortisol (a) progesterone (b) and LH (c) in 5 ovariectomized cows without stress and without E2 (treatment 1,-O-), without stress and with E2

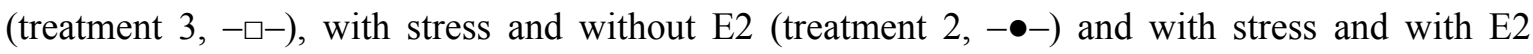
(treatment $4,--\mathbf{-}-$ ). 
Table 1

Mean ( $m \pm$ S.E.M.) plasma concentrations of cortisol, progesterone and LH in 5 ovariectomized cows exposed to different treatments during $2 \mathrm{~h}$.

\begin{tabular}{lccc}
\hline Treatment & Cortisol (ng/ml) & Progesterone (ng/ml) & LH (ng/ml) \\
\hline Without stress / without E2 & $3.9 \pm 0.49^{\mathrm{a}}$ & $0.3 \pm 0.04^{\mathrm{a}}$ & $1.5 \pm 0.06$ \\
Without stress / with E2 & $5.7 \pm 0.62^{\mathrm{a}}$ & $0.3 \pm 0.03^{\mathrm{a}}$ & $1.4 \pm 0.07$ \\
With stress / without E2 & $33.8 \pm 3.01^{\mathrm{b}}$ & $1.2 \pm 0.15^{\mathrm{b}}$ & $1.1 \pm 0.04$ \\
& $22.3 \pm 2.22^{\mathrm{b}}$ & $0.5 \pm 0.06^{\mathrm{a}}{ }^{\mathrm{b}}$ & $1.1 \pm 0.05$ \\
\hline With stress / with E2 & & \\
\hline
\end{tabular}

Means with different superscripts $(a, b)$ within columns are significantly different $(P<0.05)$

\subsection{Plasma concentrations of progesterone}

Mean ( $m \pm$ S.E.M.) plasma progesterone concentrations in cows with and without stress either treated or not treated with E2 are shown in Fig. 1b. During restraint stress the mean progesterone concentrations gradually increased to a maximum of $1.8 \pm 0.7 \mathrm{ng} / \mathrm{ml}$ in untreated cows and were significantly $(P<0.05)$ higher than mean values in non stressed cows (Table 1). The stress induced progesterone increase in E2-treated cows was lower and not significantly $(P<0.05)$ different from untreated cows and all animals without stress. Under stress the mean plasma progesterone values ranged between $0.4-1.8 \mathrm{ng} / \mathrm{ml}$ in untreated cows while in E2-treated and in all animals without stress the concentrations fluctuated between $0.3-0.7 \mathrm{ng} / \mathrm{ml}$.

Individual plasma progesterone concentrations during the whole experiment in all cows without and with E2 treatment are shown in Fig. 2. When not treated with E2, four of the five animals demonstrated a clear increase in plasma progesterone concentrations with the stress challenge (Fig. 2a). During the E2-treated stress challenge (Fig. 2b), plasma progesterone increased in only two of four cows. In addition, the stress induced 
progesterone rise differed individually with maximum values of $4 \mathrm{ng} / \mathrm{ml}$ in E2-untreated and $1.2 \mathrm{ng} / \mathrm{ml}$ plasma in treated cows.
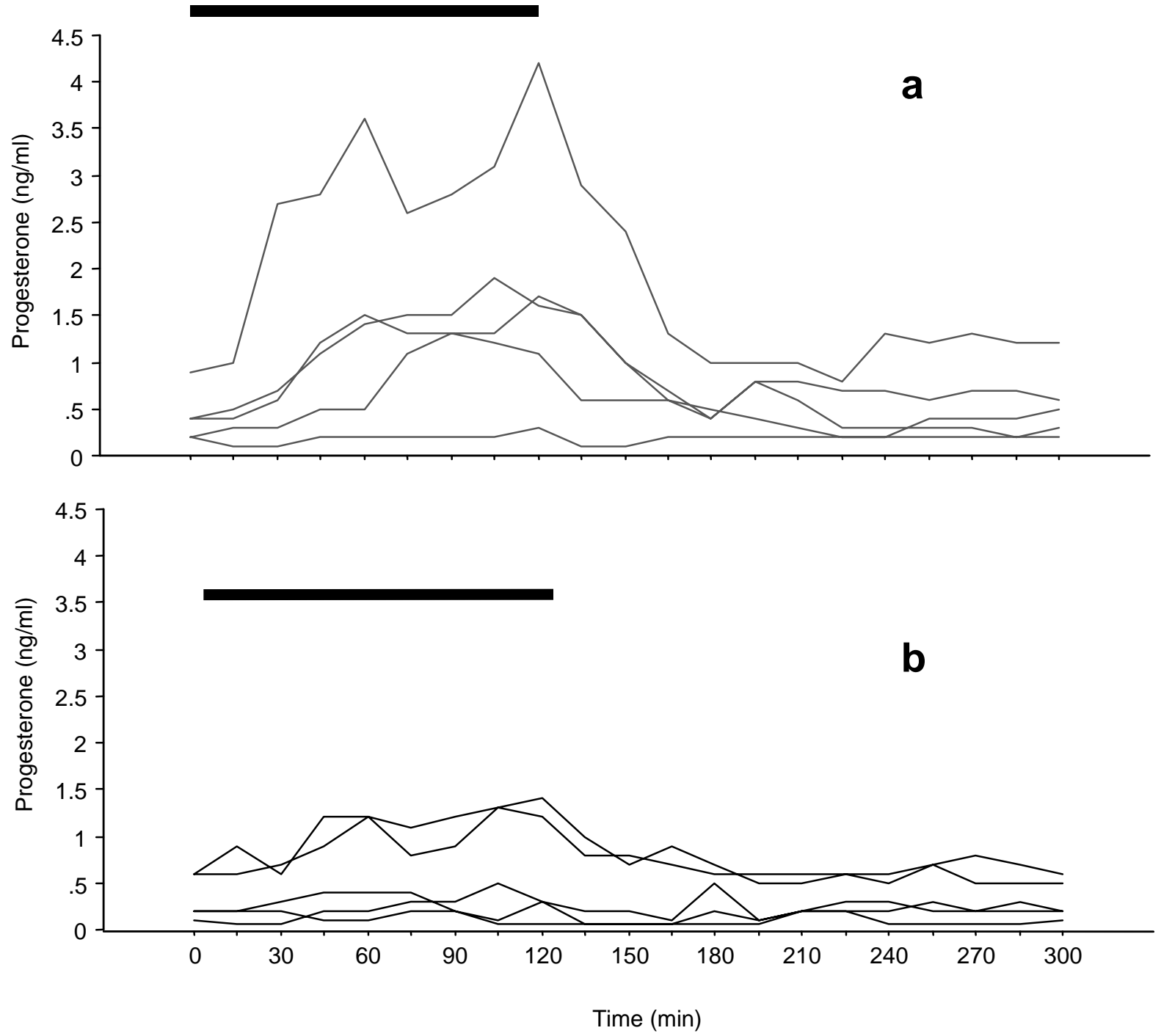

Fig. 2. Individual plasma progesterone concentrations in 5 ovariectomized cows without (a) and with (b) estradiol treatment. The black bar represents stress.

\subsection{Plasma concentrations of $L H$}

Mean ( $\mathrm{m} \pm$ S.E.M.) plasma LH concentrations did not differ significantly between treatments (Table 1), however, there was a tendency for LH concentrations to decline with 
stress challenge, regardless of E2 treatment. Mean LH concentrations before and after $120 \mathrm{~min}$ of stress challenge were significantly different $(\mathrm{P}<0.05$, paired $t$-test; Fig. $1 \mathrm{c})$.

\section{Discussion}

Results from our study indicate that in ovariectomized cows plasma cortisol concentrations showed a significant increase during the 2-h stress challenge, regardless of E2 treatment. Peak values of $80 \mathrm{ng} / \mathrm{ml}$ found in this study were similar to those reported previously (Echternkamp, 1984; Hein and Allrich, 1992; Kaufmann, 1997). Furthermore, our results demonstrate that untreated cows reacted with a ten-fold increase in cortisol but only a fivefold rise was observed when treated with E2. A clear inhibition of cortisol secretion by E2 during acute stress has also been shown in ovariectomized sheep (Komesaroff et al., 1998) and in the ovariectomized Rhesus monkey (Xia-Zhang et al., 1995). In the latter study adrenal cortex inhibition by E2 was found to be dose dependent. In contrast to the inhibitory activity, E2 was also capable to stimulate the release of cortisol in ovariectomized rats (Burgess and Handa, 1992; Carey et al., 1995). Furthermore, studies in intact cycling cows have shown that there was no difference in cortisol increases between cows in estrus or diestrus (Kaufmann, 1997; Thun et al., 1998). A likely explanation for the inhibitory action of E2 on cortisol secretion observed in the present study are the high E2 levels ranging between $20-50 \mathrm{pg} / \mathrm{ml}$ plasma. Such concentrations are normally seen only during late pregnancy but not during estrus. Apart from high circulating estrogen levels, species differences as well as the reproductive status (cycling, pregnant, ovariectomized) should also be considered when evaluating the E2 effects on the HPA axis.

Plasma progesterone increased in four of five untreated cows when exposed to stress. This confirms the observation of Thun et al. (1998), that in cycling cows, acute stress may lead to an increased production of progesterone from the adrenal cortex. Similar results have 
also been obtained in ovariectomized cows (Hein and Allrich, 1992; Bage et al., 2000) and in male calves (Cooper et al., 1995) after ACTH administration. Under the influence of estradiol, however, only 2 of 5 cows responded with a rise in plasma progesterone which was clearly lower than in untreated cows. From these results we conclude that E2 may inhibit ACTH-dependent adrenocortical secretion either by acting on the hypothalamus/pituitary system or directly on the adrenal cortex. Because ACTH and testosterone were not measured in the present study the exact site of action remains speculation. In addition, the progesterone rise during stress showed a clearly individual pattern, an observation also reported in previous studies (Verkerk et al., 1994; Kaufmann, 1997; Thun et al., 1998). The development of such a specific stress-induced hormone secretion may depend on genetic predisposition as well as on pre- and postnatal experiences (Lay et al., 1997; Liu et al., 1997) or habituation by repeated stress exposures. In our study we carefully planned the two stress treatments to be at least 14 days apart.

During stress, all animals responded with a decrease in mean plasma LH concentrations, regardless of E2 treatment. A stress dependent inhibition of LH has also been recorded in ovariectomized rats (Kam et al., 2000) and sheep (Tilbrook et al., 1999a) most likely caused by elevated stress hormones and progesterone (Rhodes et al., 2003) acting through negative feedback on both the hypothalamus and/or pituitary gland. Under the influence of E2 the slope of decrease of mean LH concentrations during stress was smaller than without E2 treatment. Similar findings in the response of LH secretion have been reported in immobilized ovariectomized rats to estradiol application (Higuchi et al., 1986). However, the LH reaction depended on the pretreatment time elapsed before stress application. When E2 was given 6-12 h before stress, an inhibitory effect was observed but when given 24-48 $\mathrm{h}$ before stress, LH secretion was stimulated. This demonstrates that apart from species differences and the level of E2, the exposure time may also influence LH release during stress. In our study cows were exposed to 6 days with E2 before stress and it is difficult to 
speculate what results may had occurred using different E2 treatments. In the present investigation, mean plasma LH concentrations between E2 treated and untreated cows without stress were not significantly different. These findings are consistent with results from a study by Looper et al. (2003), who found no changes in plasma LH levels in ovariectomized cows, either treated with estradiol or progesterone or a combination of both. These result differ from findings in ovariectomized non stressed cows (Price and Webb, 1988; Wolfe et al., 1992) and sheep (Moss et al., 1981) in which an estradiol dependent inhibition of LH secretion was observed. In another study (Rhodes et al., 2003) with ovariectomized cows, it has been shown that estradiol benzoate given 3 days following an intravaginal insert containing $1.38 \mathrm{~g}$ of progesterone did exert an additional reduction of mean LH concentrations. This finding, however, may not be compared with results of our study in which E2 priming was initiated several days before the stress challenge. The inconsistent results reported by various researchers could in part be explained by differences in the experimental design, especially regarding E2 treatment (duration and dose), the presence of progesterone as well as the type, intensity and duration of stress. Furthermore, comparison with our results is difficult to accomplish because in our experiment the effect of E2 on cortisol, progesterone and LH secretion was primarily evaluated during the 2-h stress period. Long term effects after an acute stress challenge and the question to what extent E2 is acting on central structures (hypothalamus/pituitary gland) or in the periphery (adrenal gland) requires further research.

From our experiment we conclude that in ovariectomized cows acute restraint stress increases cortisol and progesterone secretion from the adrenal cortex and decreases pituitary LH release. In addition, we observed that under the influence of estradiol the individual stress induced hormone responses were attenuated. 


\section{References}

Bage R., Forsberg M., Gustafsson H., Larsson B., Rodriguez-Martinez H., 2000. Effect of ACTH-challenge on progesterone and cortisol levels in ovariectomized repeat breeder heifers. Anim. Reprod. Sci. 63, 65-76.

Barbarino A., De Marinis L., Tofani A., Della Casa S., D'Amico C., Mancini A., Corsello S.M., Sciuto R., Barini A., 1989. Corticotropin-releasing hormone inhibition of gonadotropin release and the effect of opioid blockade. J. Clin. Endocrinol. Metab. 68, $523-528$.

Burgess L.H., Handa R.J., 1992. Chronic estrogen-induced alterations in adrenocorticotropin and corticosterone secretion, and glucocorticoid receptor-mediated functions in female rats. Endocrinology 131, 1261-1269.

Caraty A., Miller D.W., Delaleu B., Martin G.B., 1997. Stimulation of LH secretion in sheep by central administration of corticotrophin-releasing hormone. J. Reprod. Fertil. 111, 249-257.

Carey M.P., Deterd C.H., de Koning J., Helmerhorst F., de Kloet E.R., 1995. The influence of ovarian steroids on hypothalamic-pituitary-adrenal regulation in the female rat. J. Endocrinol. 144, 311-321.

Chen M.D., 1996. The insulin hypoglycemia-induced inhibition of gonadotropin-releasing hormone pulse generator activity in the rhesus monkey: roles of vasopressin and corticotropin-releasing factor. Endocrinology 137, 2012 -2021.

Chen M.D., O'Byrne K.T., Chiappini S.E., Hotchkiss J., Knobil E., 1992. Hypoglycemic "stress" and gonadotropin-releasing hormone pulse generator activity in the rhesus monkey: role of the ovary. Neuroendocrinology. 56, 666-673. 
Chrousos G.P., Torpy D.J., Gold P.W., 1998. Interactions between the hypothalamicpituitary-adrenal axis and the female reproductive system: clinical implications. Ann. Intern. Med. 129, 229-240.

Cooper C., Evans A.C.O., Cook S., Rawlings N.C., 1995. Cortisol, progesterone and $\beta$ endorphin response to stress in calves. Can. J. Anim. Sci. 95, 197-201.

Da Rosa G.O., Wagner W.C., 1981. Adrenal-gonad interactions in cattle. Corpus luteum function in intact and adrenalectomized heifers. J. Anim. Sci. 52, 1098-1105.

Daley C.A., Sakurai H., Adams B.M., Adams T.E., 2000. Effect of stress-like concentrations of cortisol on the feedback potency of estradiol in orchidectomized sheep. Anim. Reprod. Sci. 59, 167-78.

Dobson H., 1987. Effect of transport stress on luteinizing hormone released by GnRH in dairy cows. Acta Endocrinol. 115, 63-66.

Dobson H., Smith R.F., 1995: Stress and reproduction in farm animals. J. Reprod. Fertil. Suppl. 49, 451-461.

Dobson H., Ghuman S., Prabhakar S., Smith R., 2003: A conceptual model of the influence of stress on female reproduction. Reproduction 125, 151-163.

Echternkamp S.E., 1984. Relationship between LH and cortisol in acutely stressed beef cows. Theriogenology 22, 305-311.

Ferin M., 1999. Clinical review 105: Stress and the reproductive cycle. J. Clin. Endocrinol. Metab. 84, 1768-1774.

Gindoff P.R., Ferin M., 1987. Endogenous opioid peptides modulate the effect of corticotropin-releasing factor on gonadotropin release in the primate. Endocrinology 121, 837-842. 
Hahn J.D., Kalamatianos T., Coen C.W., 2003. Studies on the neuroanatomical basis for stress-induced oestrogen-potentiated suppression of reproductive function: evidence against direct corticotropin-releasing hormone projections to the vicinity of luteinizing hormone-releasing hormone cell bodies in female rats. J. Neuroendocrinol. 15, 732-742.

Hein K.G., Allrich R.D., 1992. Influence of exogenous adrenocorticotropic hormone on estrous behaviour in cattle. J. Anim. Sci. 70, 243-247.

Higuchi T., Honda K., Negoro H., 1986. Influence of oestrogen and noradrenergic afferent neurones on the response of LH and oxytocin to immobilization stress. J. Endocrinol. 110, $245-50$.

Kam K., Park, Y., Cheon M., Son G.H., Kim K., Ryn K., 2000. Effects of immobilization stress on estrogen-induced surges of luteinizing hormone and prolactin in ovariectomized rats. Endocrine 12, 279-287.

Kam K.Y., Park Y.B., Cheon M.S., Kang S.S., Kim K., Ryu K., 2002. Influence of GnRH agonist and neural antagonists on stress-blockade of LH and prolactin surges induced by 17beta-estradiol in ovariectomized rats. Yonsei Med. J. 43, 482-90.

Kaufmann C., 1997. Einfluss von akutem Stress auf den Sexualzyklus beim Rind. Doctoral Thesis, University of Zürich, Zürich, Switzerland.

Komesaroff P.A., Esler M., Clarke I.J., Fullerton M.J., Funder J.W., 1998. Effects of estrogen and estrous cycle on glucocorticoid and catecholamine responses to stress in sheep. Am. J. Physiol. 275, 671-678.

Lay DC Jr., Randel R.D., Friend T.H., Jenkins O.C., Neuendorff D.A., Bushong DM., Lanier EK., Bjorge MK., 1997. Effects of prenatal stress on suckling calves. J.Anim. Sci. $75,3143-3151$. 
Li X.F., Bowe J.E., Mitchell J.C., Brain S.D., Lightman S.L., O'Byrne K.T., 2004. Stressinduced suppression of the gonadotropin-releasing hormone pulse generator in the female rat: a novel neural action for calcitonin gene-related peptide. Endocrinology 145, 15561563.

Liu D., Diorio J., Tannenbaum B., Caldji C., Francis D., Freedman A., Sharma S., Pearson D., Plotsky P.M., Meaney M.J., 1997. Maternal care, hippocampal glucocorticoid receptors, and hypothalamic-pituitary-adrenal responses to stress. Science 277, 1659-1662.

Looper M.L., Vizcarra J.A., Wettemann R.P., Malayer J.R., Braden T.D., Geisert R.D., Morgan G.L., 2003. Influence of estradiol, progesterone, and nutrition on concentrations of gonadotropins and GnRH receptors, and abundance of mRNA for GnRH receptors and gonadotropin subunits in pituitary glands of beef cows. J. Anim. Sci. 81, 269-278.

Meyer H.H.D., 1990. Immunoaffinity chromatography and a biotin-streptavidin amplified enzyme immunoassay for sensitive and specific estimation of estradiol-17ß. J. Steroid Biochem. 35, 263-269.

Moss G.E., Crowder M.E., Nett T.M., 1981. GnRH-receptor interaction. VI. Effect of progesterone and estradiol on hypophyseal receptors for $\mathrm{GnRH}$, and serum and hypophyseal concentrations of gonadotropins in ovariectomized ewes. Biol. Reprod. 25, 938-944.

Nanda A.S., Dobson H., Ward W.R., 1990. Relationship between an increase in plasma cortisol during transport-induced stress and failure of estradiol to induce a luteinising hormone surge in dairy cows. Res. Vet. Sci. 49, 25-28.

Naylor A.M., Porter D.W., Lincoln D.W., 1990. Central administration of corticotrophinreleasing factor in the sheep: effects on secretion of gonadotrophins, prolactin and cortisol. J. Endocrinol. 124, 117-125. 
Ozturk M., Smith R.F., Dobson H., 1998. Effect of prolonged exposure to estradiol on subsequent LH secretion in ewes. J. Reprod. Fertil. 114, 1-9.

Price C.A., Webb R., 1988. Steroid control of gonadotropin secretion and ovarian function in heifers. Endocrinology 122, 2222-2231.

Rhodes F.M., Chagas L.M., Clark B.A., Verkerk G.A., 2003. Effect of dietary intake on steroid feedback on release of luteinizing hormone in ovariectomized cows. Reprod. Fertil. Develop. 15, 11-17.

Rivest S., Rivier C., 1995. The role of corticotropin-releasing factor and interleukin-1 in the regulation of neurons controlling reproductive functions. Endocr. Rev. 16, 177-99.

Rivier C., Rivest S., 1991: Effect of stress on the activity of the hypothalamic-pituitarygonadal axis: peripheral and central mechanisms. Biol. Reprod. 45, 523-532.

Saketos M., Sharma N., Santoro N.F., 1993. Suppression of the hypothalamic-pituitaryovarian axis in normal women by glucocorticoids. Biol. Reprod. 49, 1270-1276.

Sauerwein H., 1991. Quantitation of glucocorticoid receptors in bovine skeletal muscle. J. Steroid Biochem. 39, 941-945.

Schams D., Karg H., 1969. Radioimmunologische LH-Bestimmung im Blutserum vom Rind unter besonderer Berücksichtigung des Brunstzyklus. Acta Endocrinol. 61, 96-103.

Selye H., 1932. Effect of adaptation to various damaging agents on the female sex organs in the rat. Endocrinology 25, 615-624.

Smith R.F., Dobson H., 2002. Hormonal interactions within the hypothalamus and pituitary with respect to stress and reproduction in sheep. Domest. Anim. Endocrinol. 23, $75-85$. 
Stoebel D.P., Moberg G.P., 1982. Repeated acute stress during the follicular phase and luteinizing hormone surge of dairy heifers. J. Dairy Sci. 65, 92-96.

Thun R., Kaufmann K., Janett F., 1998. The influence of restraint stress on reproductive hormones in the cow. Reprod. Domest. Anim. 33: 255-260.

Tilbrook A.J., Canny B.J., Serapiglia M.D., Ambrose T.J., Clarke I.J., 1999a. Suppression of the secretion of luteinizing hormone due to isolation/restraint stress in gonadectomised rams and ewes is influenced by sex steroids. J. Endocrinol. 160, 469-481.

Tilbrook A.J., Canny B.J., Stewart B.J., Serapiglia M.D., Clarke I.J., 1999b. Central administration of corticotrophin releasing hormone but not arginine vasopressin stimulates the secretion of luteinizing hormone in rams in the presence and absence of testosterone. J. Endocrinol. 162, 301-311.

Tilbrook A.J., Turner A.I., Clarke I.J., 2000. Effects of stress on reproduction in nonrodent mammals: the role of glucocorticoids and sex differences. Rev. Reprod. 5, 105-113.

Turner A.I., Canny B.J., Hobbs R.J., Bond J.D., Clarke I.J., Tilbrook A.J., 2002. Influence of sex and gonadal status of sheep on cortisol secretion in response to ACTH and on cortisol and LH secretion in response to stress: importance of different stressors. J. Endocrinol. 173, 113-122.

Verkerk G.A., Macmillan K.L., McLeay L.M., 1994. Adrenal cortex response to adrenocorticotropic hormone in dairy cattle. Domest. Anim. Endocrinol. 11, 115-123.

Wolfe M.W., Roberson M.S., Stumpf T.T., Kittok R.J., Kinder J.E, 1992. Circulating concentrations and pattern of luteinizing hormone and follicle-stimulating hormone in circulation are changed by the circulating concentration of 17 beta-estradiol in the bovine male and female. J. Anim. Sci. 70, 248-253. 
Xiao E., Luckhaus J., Niemann W., Ferin M., 1989. Acute inhibition of gonadotropin secretion by corticotropin-releasing hormone in the primate: are the adrenal glands involved? Endocrinology, 124, 1632-1637.

Xia-Zhang L., Xiao E., Ferin M., 1995. A 5-day estradiol therapy, in amounts reproducing concentrations of the early-mid follicular phase, prevents the activation of the hypothalamo-pituitary-adrenal axis by interleukin-1 alpha in the ovariectomized rhesus monkey. J. Neuroendocrinol. 7, 387-392. 


\section{Lebenslauf}

Name

Geburtsdatum

Geburtsort

Nationalität

Heimatort

$1983-1989$

$1989-1996$

$1996-1997$

$1997-2001$

2001

2001-2004

Seit 2004

25.08.2005
Kathrin Hollenstein

09.08 .1976

St. Gallen

Schweiz

Bichelsee TG

Primarschule Rossrüti,

Sekundarschule St. Katharina, Wil, Kantonsschule Wattwil Abschluss Matura Typus C

Studium der Veterinärmedizin an der Universität Fribourg, Schweiz

Studium der Veterinärmedizin an der Universität Zürich, Schweiz

Abschlussprüfung an der Veterinärmedizinischen Fakultät der Universität Zürich, Schweiz

Doktorandin an der Klinik für Fortpflanzungsmedizin, Vetsuisse-Fakultät Universität Zürich

Assistentin in der Gemeinschaftspraxis Dres. med. vet Leuch \& Uehlinger, Beringen 